\title{
The relationship between CA repeat polymorphism of the IGF-1 gene and the structure of motor skills in young athletes
}

\author{
Krzysztof Karpowicz ${ }^{\square}$, Katarzyna Krych², Małgorzata Karpowicz ${ }^{3}$, Witold Nowak ${ }^{4}$ and \\ Piotr Gronek
}

'Department of the Theory of Sport, Poznan University School of Physical Education, Poznań, Poland; ${ }^{2}$ Department of Biology and Environmental Protection, Poznan University School of Physical Education, Poznań, Poland; ${ }^{3}$ Department of Team Sports Games, Poznan University School of Physical Education, Poznań, Poland; 4Laboratory of Molecular Biology Techniques, Adam Mickiewicz University, Poznań, Poland; ${ }^{5}$ Department of Gymnastics and Dance, Poznan University School of Physical Education, Poznań, Poland

\begin{abstract}
The map of candidate genes that can potentially affect physical fitness becomes larger every year, and they are associated with such aspects as respiratory and cardiovascular stability; body build and composition - especially muscle mass and strength; carbohydrate and lipid metabolism; response to training; and exercise intolerance.The aim of this study was to analyze the relationship between the CA repeat polymorphism of the P1 promoter of the IGF1 gene and the structure of motor skills in the two groups of Polish young athletes in 2007-2009. In this study, 350 young sportsmen representing different sports disciplines were examined (age $=15.5 \pm 0.5$ years), by genotyping the IGF1 gene and determining the structure of motor skills using the International Physical Fitness Test (IPFT) battery. The multiple stepwise regression was used to determine the impact of the investigated motor skills on the indicator of the overall physical fitness, measured by the total score of the International Physical Fitness Test (IPFT). The analysis showed some regularity related to the character of the IGF1 gene polymorphism. It can be concluded that the two groups of young boys athletes practicing various sports disciplines (kinds of physical exercise) displayed similar associations between CA repeat polymorphism of the P1 promoter of the IGF1 gene and the level of motor effects. Our results suggest that this polymorphism may be a genetic marker of the physical performance phenotype. We demonstrated that CA repeat polymorphism of the P1 promoter of the IGF1 gene was associated with strength predispositions in the homozygous and non-carriers groups. In the group who were heterozygous it was speed-strength aptitudes.
\end{abstract}

Key words: genetic variations, motor skills, young athletes

Received: 07 September, 2016; revised: 03 August, 2017; accepted: 19 February, 2018; available on-line: 15 March, 2018

e-mail: karpowicz@awf.poznan.p

Abbreviations: IGF-1, insulin-like growth factor-1; IPFT, international physical fitness test; BMI, body mass index; ACTN3, alpha-actinin 3 gene; PPAR delta, peroxisome proliferator-activated receptor delta; ACE, angiotensin convertase enzyme

\section{INTRODUCTION}

Human physical fitness, which is an indicator of selfdevelopment and health, is still the main focus of many studies concerning physical activity (Gronek \& Holdys, 2013). Investigations aimed at determining the characteristics of body conditioning that allow the achievement of high levels of sport performance are of key importance in the general training process (Tucker \& Collins, 2012). In the recruitment and selection process, the level of socalled prognostic features was once a criterion for inclusion in sports teams and rejection of those less adapted to the later stages of the training process (Vaeyens et al., 2008). Nowadays, these studies have gained more importance in planning, especially in the determination of training regimes based on the regularities of biological development (Ben-Zaken et al., 2013; Eliakim et al., 1996).

The map of candidate genes that can potentially affect physical fitness becomes larger every year, and they are associated with such aspects as respiratory and cardiovascular stability; body build and composition - especially muscle mass and strength; carbohydrate and lipid metabolism; response to training; and exercise intolerance (Pitsiladis et al., 2013; Wang et al., 2013). The inclusion of the genetic component in physiological and biochemical studies would permit drawing a representation of predispositions for each athlete interested in practicing high-performance sports and would be a valuable coaching aid in the process of training individualization (Seifert et al., 2016).

The reaction of the human body to training loads is determined by diverse gene expression (Thompson \& Binder-Macleod, 2006; Rupert, 2003). Much of the scientific interest in this area is focused on insulin-like growth factor (IGF-I), which has a wide spectrum of functions in the human body (Eliakim \& Nemet, 2010). The IGF-I protein plays a key role in regulating many cellular actions, including proliferation, differentiation, and apoptosis. IGF-I actions also involve metabolic functions, which have an impact on adaptation to physical activity (Filus \& Zdrojewicz, 2014). The association of IGF-I with physical exertion was investigated in terms of its impact on skeletal muscle. During physical exercise, IGF-I exhibits strong anabolic effects via stimulation of amino acid transport to skeletal muscle cells and activation of skeletal muscle protein synthesis (Kim et al., 1991).

Many researchers demonstrated that strength training elevates the level of IGF1 gene expression in skeletal muscles, which is connected with an increased concentration of the IGF-I protein and muscle hypertrophy (Bamman et al., 2001; Hameed et al., 2003; Philippou et al., 2007; Singh et al., 1999).

Expression of the IGF1 gene depends on both environmental and genetic factors, such as the type of tissue, level of hormones, kinds of amino acids in- 
gested with food, developmental age, and the time and intensity of the physical exercise (Jernstrom et al., 2001). It is worth mentioning that the level of circulating IGF-I protein shows large variations among individuals. It was estimated that up to $60 \%$ of interindividual differences in concentration of IGF-I are hereditary (Harrela et al., 1996). These variations reflect the expression pattern of the IGF1 gene, which can be modulated by polymorphic sequences in the promoter of this gene.

The IGF1 CA repeat polymorphism is located $\sim 1$ $\mathrm{kb}$ upstream from the transcription start site of the IGF1 gene. This region contains regulatory sequences that have an impact on P1 promoter activity. In the Caucasian population, the most common is the $(\mathrm{CA})_{19}$ repeat allele, which is 192 bps and is called the wildtype allele (Weber \& May, 1989). It was suggested that this polymorphism is related to the differences in IGF1 expression and IGF-I protein concentration in the blood. Considerable differences in skeletal muscle IGF-I concentration observed between individuals may be associated with CA repeat polymorphism of the P1 promoter of the IGF1 gene (Hand et al., 2007).

As previously noted, insulin-like growth factor-I (IGF-I) plays a key role in exercise-associated muscle growth and development (Ben-Zaken et al., 2013). The regulatory region of the promoter of the IGF-I gene is labile, but changes in this region were studied mostly in the elderly and in relation to pathological states, but rarely studied in athletes (Bamman et al., 2001; Arends et al., 2002; Fletcher et al., 2005; Hernandez et al., 2007; Rotwein et al. 1993; Widdowson et al., 2009).

Studies also indicated that single nucleotide polymorphism of the P1 promoter region of the IGF1 gene is more frequent in athletes than in non-athletes (Ben-Zaken et al., 2013; Eliakim et al., 2010). Therefore, it seems important and reasonable to consider carrying out tests to determine the presence of the gene polymorphisms and their correlation with the effects of motor skills among athletes in relation to different sports (types of physical exertion).

In light of the foregoing, the main aim of this study was the analysis of the influence of CA repeat polymorphism of the P1 promoter of the IGF1 gene on the structure of motor skills in two groups of young Polish athletes representing different sports disciplines (endurance sports, team games).

\section{MATERIAL AND METHODS}

Subjects. Data were collected over a three-year period (2007-2009) on a group of talented young athletes from the province of Greater Poland, all of who were competing in the Youth Sports System program as members of their local Provincial Junior Team. The analysis included a total of 350 boys (mean \pm S.D.: age $=15.5 \pm 0.5$ years; height $=177.8 \pm 7.98 \mathrm{~cm}$; weight $=66.8 \pm 10.29 \mathrm{~kg}$ ). Participants represented the following disciplines: athletics (track \& field) $(n=58)$, canoeing $(n=61)$, cycling $(n=57)$, rowing $(n=30)$, basketball $(n=33)$, field hockey $(n=37)$, handball $(n=35)$, and volleyball $(n=39)$.

All examined athletes were divided into two groups according to the Farfel's concept of motor coordination level (second and third level) (Farfel, 1960).

Farfel (1960) divided the categories into three levels of varying complexity. This concept was illustrated and expanded by Starosta $(1987 ; 1993)$.
The first level - has a spatial accuracy of movement activities carried out under standard conditions without a time limit.

The second level - determines the spatial precision of movement in a limited or strictly defined time, and in a standard conditions.

The third level - characterized by motor tasks performed accurately, quickly and with adjusting to changing external conditions.

The validity of this concept was confirmed by additional studies (Rutkowska-Kucharska \& Bober, 1986).

The first group consisted of athletes representing endurance sports of the second level of coordination, which involves the accuracy of movements performed in the shortest possible time or for a pre-defined time in constant and relatively invariable conditions (canoeing, cycling, athletics, rowing). The second group was players practicing team games (the third level of coordination), which requires performing the shortest possible movements while maintaining spatial accuracy under constantly changing conditions resulting from opponents' activities (basketball, field hockey, handball, and volleyball).

The measurements were made every year in the second half of March in the facilities of the university. These specific dates were due to the temporal structure of training for young athletes. They were preparing for the finals of the National Youth Olympic Games.

The research presented in this paper was conducted in accordance with the ethical standards of the Declaration of Helsinki (Ethical Principles for Research Involving Human Subjects). Participants and their parents or caregivers were informed of the testing procedures and gave their written informed consent. The study was approved by the local Research Ethics Committee (Karol Marcinkowski Medical University in Poznań, Poland, resolution numbers 712/05 and 519/07).

Procedures. Genomic DNA was isolated from epithelial cells taken from the mouth using a sterile cotton swab and a standard isolation kit (A\&A Biotechnology). IGF1 CA repeat polymorphisms were determined by PCR amplification. PCR was performed using primers designed to amplify the polymorphic (CA)n repeat $1 \mathrm{~kb}$ upstream of the human IGF1 gene (dbSNP: RS10665874). The reaction was carried out in a final volume of $15 \mu \mathrm{l}$ containing 2-3 $\mu \mathrm{l}$ of total DNA sample isolated from the buccal swabs, 3.75 pmol of the forward primer (5'-AAGAAAACACACTCTGGCAC-3') labeled with FAM, 3.75 pmol of the reverse primer (5'-ACCACTCTGGGAGAAGGGTA-3'), $0.1 \mathrm{M} \mathrm{mM}$ of deoxy-NTP, $1.5 \mathrm{mM} \mathrm{MgCl}_{2}$, 1x PCR buffer and $0.6 \mathrm{U}$ of HiFi DNA polymerase (Novazym).

Two-step PCR was performed in a 2720 thermal cycler (Applied Biosystems) with the following parameters: $94^{\circ} \mathrm{C}$ for $4 \mathrm{~min} ; 28$ cycles of $5 \mathrm{~s}$ at $94^{\circ} \mathrm{C}, 30 \mathrm{~s}$ at $60^{\circ} \mathrm{C}$ and completed with a final extension for $30 \mathrm{~min}$ at $65^{\circ} \mathrm{C}$. The size of the PCR products was analyzed by means of an automated sequencing apparatus (ABI 3130xl; POP-7 gel, filter set G5, array length $36 \mathrm{~cm}$; GeneMapper software version 3.7 ). The size of the PCR products was determined by comparing with the internal GS600LIZ size standard (Applied Biosystems). The estimation of CA repeat numbers in each analysed specimen was based on extrapolation of the previously developed specific allelic ladder. The ladder marker consisted of 14 sequenced amplicons representing alleles with 7, 9, 11, and 13-23 $\mathrm{CA}$ repeats.

We used the $\mathrm{X}^{2}$ test to determine if IGF1 genotypes were in Hardy-Weinberg equilibrium. 
The measurements focused on the level and structure of motor effects in the athletes studied. For this purpose, we used the International Physical Fitness Test (IPFT) battery, which included eight simple tests that were complementary enough to allow a comprehensive evaluation of physical fitness. With its 40-plus-year history, the IPFT was widely used by numerous coaches and researchers who applied use of this non-complex method to evaluate the effective aspect of human motor activity (Szopa et al., 2000). The IPFT battery is also recommended by the Ministry of Sport and Tourism in Poland as a tool for evaluation of physical fitness of young talented athletes.

Measurements of motor skills and flexibility were carried out according to the recommendations of the IPFT battery (Pilicz, 2004; Rosandich, 1999). Speed was evaluated by means of a 50 -meter sprint test, also termed a short run (it evaluated locomotor speed). Endurance was evaluated over a distance of 1000 meters (running endurance); agility, a $4 \times 10$-meter shuttle run with carrying blocks. Strength was tested with a standing long jump test (explosive power of lower limbs) and 30-second sit-ups (strength endurance of trunk muscles). Handgrip strength was tested by means of a handgrip dynamometer, whereas upper limb strength and shoulder girdle strength was evaluated with the bent-arm hang or a pull-up test on a bar. Trunk flexibility is an anatomical trait of a person, with a standing trunk flexion test used to reveal the scope of the vertebral column and hip joint movement.

The results obtained in each attempt of the International Physical Fitness Test were converted on a scale of 0 to 100 points (calculated according to the $\mathrm{T}$ scale), depending on the surveyed calendar age, which in the sport of children and young people is the main criterion of qualifications to training groups at different stages of training.

We also measured basic somatic parameters such as body height and weight and calculated BMI (Body Mass Index).

Statistical analyses. We used basic statistical methods for analysis of the data. The following software programs were employed: Statistica $10 \mathrm{PL}$ and Microsoft Office 2010. The statistics calculated included arithmetic
Table 1. Allele distribution of the IGF1 (CA $)_{n}$ genotype in athletes.

\begin{tabular}{lcc}
\hline \multirow{2}{*}{ Allele } & \multicolumn{2}{c}{ Coordination level } \\
\cline { 2 - 3 } & $\mathrm{n}=206$ & $\begin{array}{c}\text { III } \\
\mathrm{n}=144\end{array}$ \\
\hline $192 / 192$ & $91(44.18 \%)$ & $67(46.53 \%)$ \\
\hdashline $192 /-$ & $90(44.17 \%)$ & $59(40.97 \%)$ \\
\hline$-/-$ & $25(12.14 \%)$ & $18(12.50 \%)$ \\
\hline
\end{tabular}

Legend: 192/192 genotype homozygous for the IGF1 192-bp allele; 192/- genotypes heterozygous for the IGF1 192-bp allele; -/- genotypes of non-carriers of the IGF1 192-bp allele

mean, standard deviation, and minimum and maximum. The results were normalized with respect to the mean and standard deviations.

The multiple regression method was used to determine whether motor skills correlated with CA repeat polymorphism of the IGF1 gene (Stanisz, 2006).

\section{RESULTS}

IGF1 CA genotypes were classified according to the presence of the most frequent allele, 192bp, which contains 19 CA repeats. Athletes were classified as homozygous or heterozygous for the 192-bp allele or non-carriers of the 192-bp allele.

Genotype and alleles distributions were in HardyWeinberg equilibrium. The numbers of identified repeats were between 9 and 21 .

The genotype distribution for microsatellite repeats $(\mathrm{CA})_{\mathrm{n}}$ in athletes from II and III coordination levels is presented in Table 1.

Table 2 presents the statistical summary of the results (average, minimum, maximum). Characteristics concern the division of athletes due to the level of motor coordination.

Figures 1-2 and Tables 3-4 present the results of stepwise multiple regression analysis. The analysis was performed by the level of coordination.

Table 2. Statistical characterization of the results (based on the level of coordination).

Athletes - level II of motor coordination Athletes - level III of motor coordination

\begin{tabular}{|c|c|c|c|c|c|c|c|}
\hline & & \multicolumn{3}{|c|}{$n=206$} & \multicolumn{3}{|c|}{$\mathrm{n}=144$} \\
\hline & & & Min. & Max. & & Min. & Max. \\
\hline Body height & $\mathrm{cm}$ & 178 & 161 & 198 & 178 & 152 & 210 \\
\hline Body mass & $\mathrm{kg}$ & 68 & 46 & 98 & 66 & 39 & 123 \\
\hline Bmi & $\mathrm{kg} / \mathrm{m}^{2}$ & 21 & 16 & 29 & 21 & 15 & 32 \\
\hline Speed & pts. & 58 & 32 & 82 & 59 & 29 & 78 \\
\hline Leg strength & pts. & 55 & 32 & 86 & 59 & 34 & 84 \\
\hline Endurance & pts. & 59 & 30 & 75 & 55 & 33 & 67 \\
\hline Hand strength & pts. & 55 & 34 & 76 & 52 & 28 & 99 \\
\hline Shoulders strength & pts. & 60 & 10 & 98 & 43 & 10 & 73 \\
\hline Agility & pts. & 56 & 21 & 78 & 62 & 34 & 74 \\
\hline Strength endurance & pts. & 57 & 26 & 77 & 59 & 40 & 79 \\
\hline Flexibility & pts. & 55 & 27 & 74 & 55 & 27 & 73 \\
\hline Sum of ipft & pts. & 455 & 316 & 554 & 444 & 296 & 542 \\
\hline
\end{tabular}




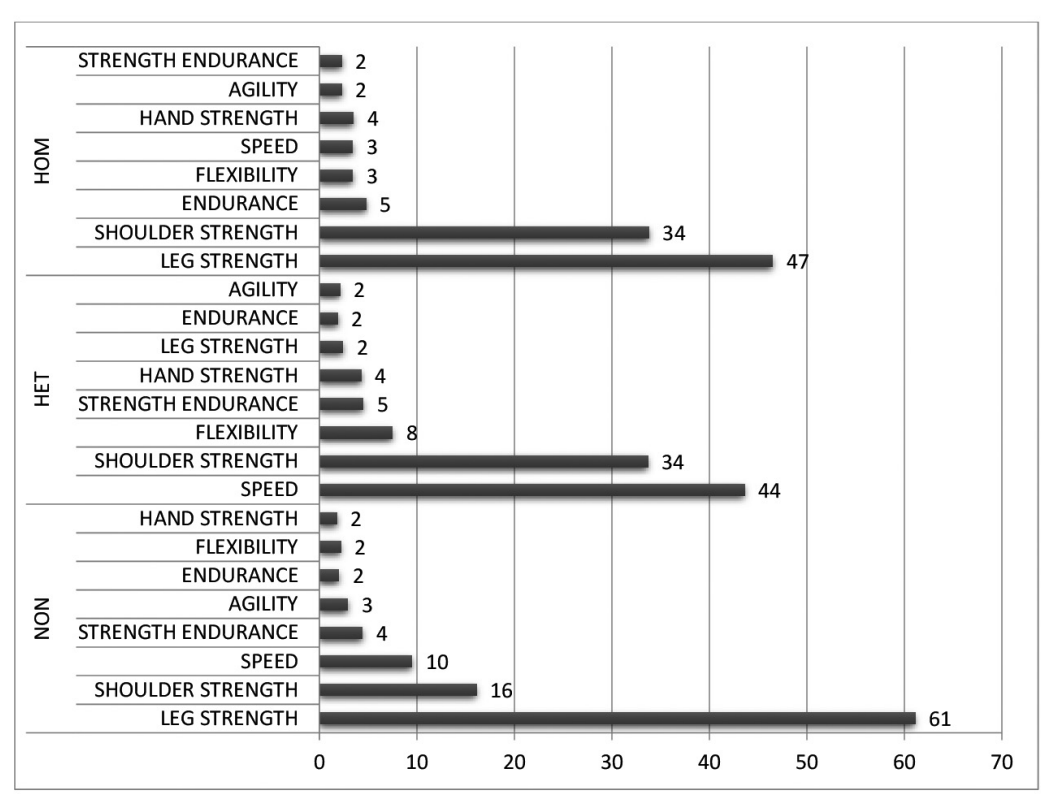

Figure 1. The results of multiple regressions for endurance sports - II level of coordination (\%).

In the group of endurance athletes (the second level of coordination), determinants of the overall physical fitness, measured by scores of the IPFT, were similar to the group of all studied athletes. Physical fitness of the athletes homozygous for the 192-bp allele in $81 \%$ of individuals, was conditioned by the leg power and shoulder strength. Similar results as in the group of homozygous athletes were found for sportsmen who were non-carriers of the 192-bp allele. In heterozygous athletes, the physical fitness in $77 \%$ of individuals, was conditioned by speed predispositions and shoulder strength (Fig. 1, Table 3).

A similar result was shown in athletes of team games (the third level of coordination). In homozygous athletes,

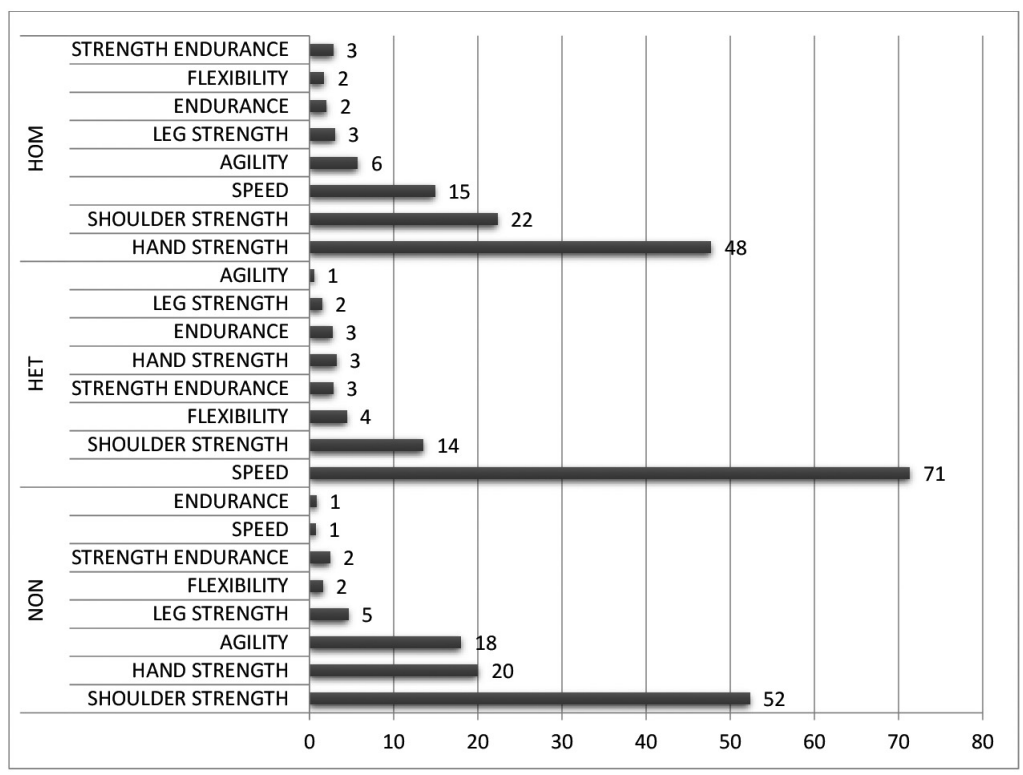

Figure 2. The results of multiple regressions for team games - III level of coordination (\%). the greatest extent $(85 \%)$ of the level of motor effects was determined by shoulder and hand strength as well as speed predispositions. In athletes who were heterozygous for the 192-bp allele, the most important determinants of the overall physical fitness were speed predispositions. In the group of non-carriers of the 192-bp allele, the dependent variable was determined by shoulder and hand strength as well as by agility predispositions (Fig. 2, Table 4).

\section{DISCUSSION}

The way in which an organism adapts to physical exertion depends, among others, on the regulation of many genes' expression e.g. IGF1, ACTN3, PPAR delta, ACE (Karlowatz et al., 2011; Jung et al., 2016; Maciejewska-Karłowska, 2013; Orysiak et al., 2015; Holdys et al., 2011). Their polymorphism turned out to be an important factor that influences the level of physical performance (Scheinowitz et al., 2003). Among those genes, IGF1 plays a remarkable role because of the broad spectrum and specificity of its action. It is known that the regulatory region of the $\mathrm{P} 1$ promoter of this gene is labile (Mukherjee et al., 2016).

This manifests itself by a significant degree of single nucleotides variation and by the presence of the different number of microsatellite repeats (CA) (Wong et al., 2005). These changes were analyzed in relation to various pathological states (Fletcher et al., 2005; Hernandez et al., 2007; Zhai et al., 2004), but rarely were studied in athletes (Ben-Zaken et al., 2013; Ben-Zaken et al., 2014).

IGF-I affects morpho-functional parameters of the human body, which are essential for gaining high sports performance (Bamman et al., 2001; Philippou et al., 2007; Hand et al., 2007; Kostka et al., 2000; Neri Serneri et al., 2001). The IGF-I concentration is determined by IGF1 gene expression, which may be modulated by polymorphic sequences in the P1 promoter region (Rosen et al., 1998). It is known that the sequence of the P1 promoter of the IGF1 gene is highly variable (Vaessenet al., 2001). However, better adaptation to physical exercise was associated rather with C-1245T (rs35767 C/T) (BenZakenet al., 2013) and rs1464430 A/C polymorphism (Ben-Zaken et al., 2015) of this gene than in P1 promoter. The applied approach is unique because in searching for connections between polymorphism of the IGF1 gene and physical exertion, scientists focused mainly on the impact of physical exercise on the IGF-I concentration in the blood (Monnier et al., 2000). 
Table 3. The results of multiple regression for endurance sports - II level of coordination $(n=206)$.

\begin{tabular}{|c|c|c|c|c|c|}
\hline \multirow{2}{*}{ Genotype } & \multirow{2}{*}{$\begin{array}{l}\text { Independent } \\
\text { Variables }\end{array}$} & \multicolumn{4}{|c|}{$\begin{array}{l}\text { Summary of stepwise regression; } \\
\text { Dependent variable: total pts. IPFT }\end{array}$} \\
\hline & & Step & $\begin{array}{l}\text { Multiple } \\
\text { Spearman }\end{array}$ & $\begin{array}{l}\text { Multiple } \\
\text { R-squared }\end{array}$ & $\begin{array}{l}\text { R-squared } \\
\text { change of }\end{array}$ \\
\hline \multirow{8}{*}{ HOM } & Leg strength & 1 & 0.682 & 0.465 & 0.465 \\
\hline & Shoulder strength & 2 & 0.897 & 0.804 & 0.338 \\
\hline & Endurance & 3 & 0.923 & 0.851 & 0.048 \\
\hline & Flexibility & 4 & 0.941 & 0.885 & 0.034 \\
\hline & Speed & 5 & 0.959 & 0.919 & 0.034 \\
\hline & Hand strength & 6 & 0.977 & 0.954 & 0.035 \\
\hline & Agility & 7 & 0.988 & 0.977 & 0.023 \\
\hline & Strength endurance & 8 & 1.000 & 1.000 & 0.023 \\
\hline \multirow{8}{*}{ HET } & Speed & 1 & 0.660 & 0.436 & 0.436 \\
\hline & Shoulder strength & 2 & 0.879 & 0.773 & 0.337 \\
\hline & Flexibility & 3 & 0.921 & 0.848 & 0.075 \\
\hline & Strength endurance & 4 & 0.945 & 0.893 & 0.045 \\
\hline & Hand strength & 5 & 0.968 & 0.936 & 0.043 \\
\hline & Leg strength & 6 & 0.980 & 0.960 & 0.024 \\
\hline & Endurance & 7 & 0.990 & 0.979 & 0.019 \\
\hline & Agility & 8 & 1.000 & 1.000 & 0.021 \\
\hline \multirow{8}{*}{ NON } & Leg strength & 1 & 0.782 & 0.611 & 0.611 \\
\hline & Shoulder strength & 2 & 0.879 & 0.772 & 0.161 \\
\hline & Speed & 3 & 0.931 & 0.867 & 0.095 \\
\hline & Strength endurance & 4 & 0.954 & 0.911 & 0.044 \\
\hline & Agility & 5 & 0.970 & 0.940 & 0.029 \\
\hline & Endurance & 6 & 0.980 & 0.960 & 0.020 \\
\hline & Flexibility & 7 & 0.991 & 0.982 & 0.022 \\
\hline & Hand strength & 8 & 1.000 & 1.000 & 0.018 \\
\hline
\end{tabular}

This provides indirect evidence that CA polymorphism of the IGF1 gene, which is more frequent in athletes than non-athletes (Ben-Zaken et al., 2013; KrychGarsztka et al., 2011), may have a very significant impact on achievements in many sports, by defining its occurrence and relationship with level of body adaptation to specific physical efforts. This is a particularly important issue in the case of young athletes, who, on the one, fight an intense biological development; and on the other hand, they are often exposed to excessive training loads (Gronek et al., 2015).

A significant number of studies were published in the last decade indicating that genetic variants have an influence on human physical performance and/or elite athlete status (Bray et al., 2009). The available research results constitute a large database which must be systematized before implementing genetic profiling in sport (Ruth et al., 2014). Therefore, it seems justified to conduct this type of research among young athletes representing various sports disciplines.

Analysis of the multiple stepwise regression used to determine the impact of the investigated motor skills on the indicator of the overall physical fitness, measured by the total score of the International Physical Fitness Test (IPFT), showed some regularity related to the character of the IGF1 gene polymorphism.
It can be concluded that in the case of two groups of young male athletes (15-16 years) practicing various sports disciplines (kinds of physical exercise) there is a similar association between CA repeat polymorphism of the P1 promoter of the IGF1 gene and the level of motor effects.

It was found that in the group of endurance athletes (the second level of coordination) who were homozygous for the 192-bp allele, the level of general physical fitness was determined by strength predispositions, above all, leg and shoulder strength.

In athletes of the team games (the third level of coordination) who were homozygous, the most important features that determined the overall physical fitness were strength predispositions, hand and shoulder strength and speed predispositions. In athletes who were heterozygous for the 192-bp allele, the most important determinants of the overall physical fitness were speed predispositions and shoulder strength. This situation concerns endurance athletes and the athletes of team games.

In the groups of athletes that were non-carriers of the 192-bp allele, it was shown that the level of the overall physical fitness was determined as in the case of homozygous athletes, by the leg and shoulder strength.

Increasingly high performance among athletes today causes the need for coaches to meet increasingly com- 
Table 4. The results of multiple regression for team games - III level of coordination ( $n=144)$.

\begin{tabular}{|c|c|c|c|c|c|}
\hline \multirow{2}{*}{ Genotype } & \multirow{2}{*}{$\begin{array}{l}\text { Independent } \\
\text { Variables }\end{array}$} & \multicolumn{4}{|c|}{$\begin{array}{l}\text { Summary of stepwise regression; } \\
\text { Dependent variable: total pts. IPFT }\end{array}$} \\
\hline & & Step & $\begin{array}{l}\text { Multiple } \\
\text { Spearman }\end{array}$ & $\begin{array}{l}\text { Multiple } \\
\text { R-squared }\end{array}$ & $\begin{array}{l}\text { R-squared } \\
\text { change of }\end{array}$ \\
\hline \multirow{8}{*}{$\mathrm{HOM}$} & Hand strength & 1 & 0.691 & 0.477 & 0.477 \\
\hline & Shoulder strength & 2 & 0.837 & 0.700 & 0.223 \\
\hline & Speed & 3 & 0.921 & 0.848 & 0.149 \\
\hline & Agility & 4 & 0.951 & 0.905 & 0.057 \\
\hline & Leg strength & 5 & 0.967 & 0.935 & 0.030 \\
\hline & Endurance & 6 & 0.977 & 0.954 & 0.020 \\
\hline & Flexibility & 7 & 0.986 & 0.972 & 0.017 \\
\hline & Strength endurance & 8 & 1.000 & 1.000 & 0.028 \\
\hline \multirow{8}{*}{ HET } & Speed & 1 & 0.844 & 0.713 & 0.713 \\
\hline & Shoulder strength & 2 & 0.921 & 0.848 & 0.135 \\
\hline & Flexibility & 3 & 0.945 & 0.893 & 0.044 \\
\hline & Strength endurance & 4 & 0.960 & 0.921 & 0.028 \\
\hline & Hand strength & 5 & 0.976 & 0.953 & 0.032 \\
\hline & Endurance & 6 & 0.990 & 0.980 & 0.027 \\
\hline & Leg strength & 7 & 0.997 & 0.995 & 0.015 \\
\hline & Agility & 8 & 1.000 & 1.000 & 0.005 \\
\hline \multirow{8}{*}{ NON } & Shoulder strength & 1 & 0.723 & 0.523 & 0.523 \\
\hline & Hand strength & 2 & 0,836 & 0.723 & 0.200 \\
\hline & Agility & 3 & 0.948 & 0.899 & 0.176 \\
\hline & Leg strength & 4 & 0.972 & 0.945 & 0.046 \\
\hline & Flexibility & 5 & 0.980 & 0.961 & 0.016 \\
\hline & Strength endurance & 6 & 0.993 & 0.985 & 0.024 \\
\hline & Speed & 7 & 0.996 & 0.992 & 0.007 \\
\hline & Endurance & 8 & 1.000 & 1.000 & 0.008 \\
\hline
\end{tabular}

plex and more comprehensive requirements. Facing these challenges calls for the identification of solutions aimed at reasonable and effective preparation of the athletes. Striving for champion-level achievement led to shifting the emphasis in coaching to the period of childhood and youth (Karpowicz et al., 2015).

The targeted stage of sports training is a specific period in human development, which coincides with high sensitivity of the human body to external stimuli.

Therefore, modern auxology and training methodology put a great emphasis on the necessity of systematic control of the physical development of children and young people. The problem of the assessment of this development and its components (harmony and level) becomes especially important in the context of scientific investigations of the determinants of physical activity on different stages of training and motor development (Karpowicz \& Karpowicz, 2013). The morphological characteristic is a commonly used measure of development evaluation. Considering sport teams, the assessment of biological maturity based on the characteristics, which are often a criterion for admission to various levels of locomotor activity, is not relevant to the actual biological picture of the human body (Karpowicz et al., 2015). Our results revealed the possibility of using analysis of the IGF1 gene sequence in sports. Application of molecular biology techniques may allow the identification of predispositions resulting from individual characteristics of the gene code.

Nevertheless, there still is a need for further studies to elucidate the mechanism of the functional significance of CA polymorphism in the promoter region of the IGF1 gene in regulating its expression and determining the level of the motor effects.

\section{REFERENCES}

Arends N, Johnston L, Hokken-Koelega A, Van Duijn C, de Ridder M, Savage M, Clark A (2002) Polymorphism in the IGF-I gene: clinical relevance for short children born small for gestational age (SGA).J Clin Endocrinol Metabol 87: 2720-2724. doi: 10.1210/jcem.87.6.8673

Bamman MM, Shipp JR, Jiang J, Gower BA, Hunter GR, Goodman A, McLafferty CL Jr, Urban RJ (2001) Mechanical load increase muscle IGF-I and androgen receptor mRNA concentrations in humans. Am J Physiol-Endocrinol Metabol 280: E383-E390. doi: 10.1152/ ajpendo.2001.280.3.E383

Ben-Zaken S, Meckel Y, Lidor R, Nemet D, Eliakim A (2013) Genetic profiles and prediction of the success of young athletes transition from middle- to long-distance runs: An exploratory study. Pediatr Exerc Sci 25: 435-447. doi.org/10.1016/j.ghir.2013.06.005

Ben-Zaken S, Meckel Y, Nemet D, Eliakim A (2013) Can IGF-I polymorphism affect power and endurance athletic performance? Growth Horm IGF Res 23: 175-178. doi: 10.1016/j.ghir.2013.06.005. https:// doi.org/10.1123/pes.25.3.435

Ben-Zaken S, Meckel Y, Dror N, Nemet D, Eliakin A (2014) IGF-I and IGF-I receptor polymorphisms among elite swimmers. Pediatric Exerc Sci 26: 470-476. https://doi.org/10.1016/j.jsams.2014.03.007 
Ben-Zaken S, Meckel Y, Nemet D, Eliakim Y (2015) IGF-I receptor 275124A>C (rs1464430) polymorphism and athletic performance J Sci Med Sport 18: 323-327. https://doi.org/10.1016/j. jsams.2014.03.007

Bray MS, Hagberg JM, Pérusse L, Rankinen T, Roth SM, Wolfarth $\mathrm{B}$, Bouchard C (2009) The human gene map for performance and health-related fitness phenotypes: the 2006-2007 update. Med Scl Sports Ex 41: 35-73. PMID: 19123262

Eliakim A, Brasel JA, Mohan S (1996) Physical fitness, endurance training, and the growth hormone-insulin like growth factor I system in adolescent females. J Clin Endocrinol Metab 81: 3986-3992. https:// doi.org/10.1210/jcem.81.11.8923848

Eliakim A, Nemet D (2010) Exercise training, physical fitness and the growth hormone-insulin-like growth factor-1 axis and cytokine balance. Med Sport Sci 55: 128-140. doi: 10.1159/000321977

Farfel V (1960) Physiology of Sport. Moskva (in Russian)

Filus A, Zdrojewicz Z (2014) Insulin-like growth factor-1 (IGF-1) structure and the role in the human body. Pediatr Endocrinol Diabetes Metabol 22: 161-169. doi: 10.20452/pamw.4136

Fletcher O, Gibson L, Johnson N, Altmann DR, Holly JM, Ashworth A, Peto J, Silva Idos S (2005) Polymorphisms and circulating levels in the insulin-like growth factor system and risk of breast cancer: a systematic review. Cancer Epidem Biomar 14: 2-19. PMID: 15668470

Gronek P, Holdys J (2013) Genes and physical fitness. Trends Sport Sa 1: 16-29. doi. 10.1515/biol-2015-0002

Gronek P, Holdys J, Konarski J, Kryściak J, Wolc A (2013) ACE I/D genotype in professional field hockey players. Trends Sport Sci 1: $36-40$

Gronek P, Wieliński D, Gronek J (2015) Genetic and non-genetic determinants of aggression in combat sports. Open Life Sci 10: 7-18

Hameed M, Lange KH, Andersen JL, Schjerling P, Kjaer M, Harridge SD, Goldspink G (2003) The effect of recombinant human growth hormone and resistance training on IGF-I mRNA expression in the muscles of elderly men. J Physiol 555.1: 231-240. doi: 10.1113/ jphysiol.2003.051722

Hand BD, Kostek MC, Ferrell RE, Delmonico MJ, Douglass LW, Roth SM, Hagberg JM, Hurley BF (2007) Influence of promoter region variants of insulin-like growth factor pathway genes on the strength-training response of muscle phenotypes in older adults. J Appl Physiol 103: 1678-1687. doi: 10.1152/japplphysiol.00420.2007

Harrela M, Koistinen H, Kaprio J, Lehtovirta M, Tuomilehto J, Eriksson J, Toivanen L, Koskenvuo M, Leinonen P, Koistinen R, Seppälä M (1996) Genetic and environmental components of interindividual variation in circulating levels of IGF-I, IGF-II, IGFBP-I, and IGFBP-3. J Clin Invest 98: 2612-2625. doi: 10.1172/JCI119081

Hernandez W, Grenade C, Santos E, Bonilla C, Ahaghotu C, Kittles R (2007) IGF-1 and IGFBP-3 gene variants influence on serum levels and prostate cancer risk in African-Americans. Carcinogenesis 28 2154-2159. https://doi.org/10.1093/carcin/bgm190

Holdys J, Kryściak J, Stanisławski D, Gronek P (2011) ACE I/D polymorphism in athletes of various sports disciplines. Hum Mov 12: 223-231

Jernstrom H, Deal C, Wilkin F, Chu W, Tao Y, Majeed N (2001) Genetic and nongenetic factors associated with variation of plasma levels of insulin-like growth factor-I and insulin-like growth factorbinding protein- 3 in healthy premenopausal women. Cancer Epidemiol Biom Prev 10: 377-384. PMID: 11319179

Jung H, Lee N, Park S (2016) Interaction ofACTN3 gene polymorphism and muscle imbalance effects on kinematic efficiency in combat sports_athletes. I Exerc Nutrition Biochem 20: 1-7. doi: 10.20463/ jenb.2016.06.20.2.1

Karlowatz RJ, Scharhag J, Rahnenführer J, Schneider U, Jakob E, Kindermann W, Zang KD (2011) Polymorphisms in the IGF1 signalling pathway including the myostatin gene are associated with left ventricular mass in male athletes. Br J Sports Med 45: 36-41. http://bjsm.bmj.com/content/45/1/36.full.pdfdoi: 10.1136/ bjsm.2008.050567

Karpowicz K, Karpowicz M (2013) Reflections on the changes observed in the structure of motor skills in young athletes. Hum Mov 14: 221-228. doi: 10.2478/humo-2013-0027

Karpowicz K, Karpowicz M, Strzelczyk R (2015) Structure of physical fitness among young female basketball players (trends of changes in 2006-2013). J Strength Condition Res 29: 2745-2757. doi: 10.1519/ JSC.0000000000000943

Kim SW, Lajara R, Rotwein P (1991) Structure and function of a human insulin-like growth factor-I gene promoter. Mol Endocrinol 5: 1964-1972. doi: 10.1210/mend-5-12-1964

Kostka T, Arsac L, Patricot M, Berthouze S, Lacour J, Bonnefoy M (2000) Leg extensor power and dehydroepiandrosterone sulfate, insulin-like growth factor-I and testosterone in healthy active elderly people. Eur J Appl Physiol 82: 83-90. https://doi.org/10.1007/ s0042100506

Krych-Garsztka K, Mizgajska-Wiktor H, Goździcka-Józefiak A (2011) An analysis of the regulatory region of the IGF1 gene in professional athletes in youth sports teams. Hum Mov 12: 216-222. doi: 10.2478/v10038-011-0021-y
Maciejewska-Karłowska A (2013) Polymorphic variants of the PPAR (Peroxisome Proliferator-Activated Receptor) genes: relevance for athletic performance. Trends Sport Sci 1: 5-15

Monnier JF, Benhaddad AA, Micallef JP, Mercier J, Brun JF (2000) Relationships between blood viscosity and insulin-like growth factor I status in athletes. Clin Hemorbeol Microcirc 22: 277-286. PMID: 11081465

Mukherjee A, Alzhanov D, Rotwein P (2016) Defining human insulinlike growth factor I gene regulation. Am J Physiol Endocrinol Metab 311: E519-E529. doi: 10.1152/ajpendo.00212.2016

NeriSerneri GG, Boddi M, Modesti PA, Cecioni I, Coppo M, Padeletti L, Michelucci A, Colella A, Galanti G (2001) Increased cardiac sympathetic activity and insulin-like growth factor-I formation are associated with physiological hypertrophy in athletes. Circ Res 23: 977-982. PMID: 11717153

Orysiak J, Sitkowski D, Zmijewski P, Malczewska-Lenczowska J, Cieszczyk P, Zembron-Lacny A, Pokrywka A (2015) Overrepresentation of the ACTN3 XX genotype in elite canoe and kayak paddlers I Strength Cond Res 29: 1107-1112. doi: 10.1519/ JSC.0000000000000717

Philippou A, Maridaki M, Halapas A, Koutsilieris M (2007) The role of the insulin-like growth factor 1 (IGF-1) in skeletal muscle physiology. In Vivo 21: 45-54. PMID: 17354613

Pilicz S, Charzewski J, ed (2004) Scoring physical fitness of Polish youth by International Physical Test. The criteria for measuring the capacity of the organism by the Cooper test. AWF, Warszawa (in Polish)

Pitsiladis Y, Wang G, Wolfarth B, Scott R, Fuku N, Mikami E, He Z, Fiuza-Luces C, Eynon N, Lucia A (2013) Genomics of elite sporting performance: what little we know and necessary advances. $\mathrm{Br} J$ Sports Med 47: 550-555. doi: 10.1136/bjsports-2013-092400

Rosandich TP (1999) International physical fitness test. Sport J 2: 34-45

Rotwein P, Bichell DP, Kikuchi K (1993) Multifactorial regulation of IGF-I gene expression. Mol Reprod Dev35: 358-363. doi: 10.1002/ mrd.1080350407

Rupert JL (2003) The search for genotypes that underline human performance phenotypes. Comp Biochem Physiol Part A 136: 191-203. doi: 10.1016/S1095-6433(02)00349-5

Loos RJF, Hagberg JM, Pérusse L, Roth SM, Sarzynski MA, Wolfarth B, Rankinen T, Bouchard C (2015) Advances in exercise, fitness, and performance genomics in 2014. Med Sci Sports Exerc 47: 11051112. doi:10.1249/MSS.0000000000000645

Rosen CJ, Kurland ES, Vereault D, Adler RA, Rackoff PJ, Craig WY, Witte S, Rogers J, Bilezikian JP. (1998) Association between serum insulin growth factor-I (IGF-I) and a simple sequence repeat in IGF-I gene: implications for genetic studies of bone mineral density. J Clin Endocrinol Metabol 83: 2286-2290. doi: 10.1152/japplphysiol.00420.2007

Rutkowska-Kucharska A, Bober T (1986) Of examining the physical coordination. In Motor potential of the man, Bober T ed, AWF, Warszawa. pp 116-143 (in Polish)

Scheinowitz M, Kessler-Icekson G, Freimann S, Zimmermann R, Schaper W, Golomb E, Savion N, Eldar M (2003) Short- and longterm swimming exercise training increases myocardial insulin-like growth factor-I gene expression. Growth Horm IGF Res 13: 19-25. doi: 10.1016/\$1096-6374(02)00137-5

Seifert L, De Jesus K, Komar J, Ribeiro J, Abraldes JA, Figueiredo P, Vilas-Boas JP, Fernandes RJ (2016) Behavioural variability and motor performance: Effect of practice specialization in front crawl swimming. Hum MovSci 15: 141-150. doi: 10.1016/j.humov.2016.03.007.

Singh MA, Ding W, Manfredi TJ, Solares GS, O'Neill EF, Clements KM, Ryan ND, Kehavias JJ, Fielding RA, Evans WJ (1999) Insulin-like growth factor I in skeletal muscle after weight-lifting exercise in frail elders. Am J Physiol 277: E135--E143. PMID: 10409137 Stanisz A (2006) An exchange rate statistics using STATISTICA PL on the examples of medicine. Vol. I, II, III. StatSoft Polska, Kraków (in Polish)

Starosta W (1993) Motor coordination of the man. In Human movement - the structure, the changeability and conditioning. Osiński W ed, Monografie 310, AWF, Poznań, pp 81-120 (in Polish)

Starosta W (1987) The importance of research of motor coordination for sports improvement of advanced athletes. Kultura Fizyczna 7: 3-4 (in Polish)

Szopa J, Mleczko E, Żak S (2000) The basis of anthropomotorics. PWN, Warszawa (in Polish)

Thompson WR, Binder-Macleod SA (2006) Association of genetic factors with selected measures of physical performance. Phys Ther 86: 585-591. PMCID: PMC4090215

Tucker R, Collins M (2012) What makes champions? A review of the relative contribution of genes and training to sporting success. Br J Sports Med 46: 555-56I. doi: 10.1136/bjsports-2011-090548

Vaessen N, Heutink P, Janssen JA, Witteman JC, Testers L, Hofman A, Lamberts SW, Oostra BA, Pols HA, Van Duiin CM (2001) A polymorphism in the gene for IGF-I. Functional properties and risk 
for type 2 diabetes and myocardial infarction. Diabetes 50: 637-642. PMID: 11246885

Vaeyens R, Lenoir M, Williams AM, Philippaerts RM (2008) Talent identification and development programmes in sport: current models and future directions. Sports Med 38: 703-714. doi; 10.2165/00007256-200838090-00001

Weber J, May P (1989) Abundant class of human DNA polymorphisms which can be typed using the polymerase chain reaction. Am J Hum Genet 44: 388-396. PMCID: PMC1715443

Widdowson WM, Healy ML, Sönksen PH, James Gibney J (2009) The physiology of growth hormone and sport. Growth Horm IGF Res 19: 308-319. doi: 10.1016/j.ghir.2009.04.023
Wong HL, Delellis K, Probst-Hensch N, Koh WP, Van Den Berg D, Lee HP, Yu MC, Ingles SA (2005) A new single nucleotide polymorphism in the insulin-like growth factor I regulatory region associates with colorectal cancer risk in Singapore Chinese. Cancer EpidemBiomar 14: 144-151. doi: 10.1016/j.ghir.2009.04.023

Zhai G, Rivadeneira F, Houwing-Duistermaat JJ, Meulenbelt I, Bijkerk C, Hofman A, Van Meurs JB, Uitterlinden AG, Pols HA, Slagboom PE, Van Duijn CM (2004) Insulin-like growth factor I gene promoter polymorphism, collagen type II $\alpha 1$ (COL2A1) gene, and the prevalence of radiographic osteoarthritis: the Rotterdam Study. Annu Rheumatic Dis 63: 544-548. PMID: 15082485 